\title{
Necessity of Teamwork for Paediatric Dermatologic Patients Visiting Pediatric Surgery
}

\author{
Çocuk Cerrahisinde Muayene Olan Pediatrik Dermatoloji Hastaları Için \\ Takım Çalışmasının Gerekliliği
}

\author{
Atilla ŞENAYLI ${ }^{1}$,İsmet Faruk ÖZGÜNER², Burhan KÖSEOĞLU ${ }^{1}$, Afra KARAVELIOĞLU³ , Melih AKIN4
}

\author{
${ }^{1}$ Keçiören Education and Research Hospital, Ankara, Turkey \\ ${ }^{2}$ Dr. Sami Ulus Pediatric Diseases Education Hospital, Ankara, Turkey \\ ${ }^{3}$ Zübeyde Hanım Gynaecology and Paediatric Diseases Hospital, Afyonkarahisar, Turkey \\ ${ }^{4}$ Şişli Etfal Education Hospital, İstanbul, Turkey
}

\begin{abstract}
Objective: Pediatric surgery is one of the departments treating some pediatric dermatology diseases. In this study, experience of pediatric surgeons were assessed for skin diseases. In addition, the interaction between the pediatric surgery and other relevant sections were examined.

Material and Methods: Pediatric surgery documents between 2005 and 2011 were examined. Diagnoses, consultations, and changes in diagnosis were evaluated for dermatologic problems of the patients.

Results: Three hundred and fifty-two pediatric surgical patients were examined due to dermatologic complaints. Seventy-five patients were consulted eighty times totally to other clinics. four patients were consulted twice and one patient was consulted three times. The diagnosis of 68 patients was changed after examination in different clinics.

Conclusion: Clinical disciplines for the integration of pediatric visits are rarely evaluated in dermatological patients. In our opinion, these evaluations may assist in selection of pediatric dermatologic units and medical members. Clinics of possible integrations between the common treatments for these patients may be important to design.
\end{abstract}

Key Words: Children, Dermatology, Pediatric dermatology, Pediatric surgery, Team work

\section{ÖZET}

Amaç: Pediatrik dermatoloji hastalıklarının tedavi edildiği bölümlerden biri de pediatrik cerrahidir. Bu çalışmada, pediatrik cerrahların deri hastalıkları için olan tecrübeleri değerlendirilmiştir. Ayrıca, pediatrik cerrahi ve diğer ilgili bölümlerin karşıllıkı ilişkileri de araştırımıştır.

Gereç ve Yöntemler: 2005- 2011 yıllarına ait pediatrik cerrahinin dokümanları incelenmiștir. Teșhisler, konsültasyonları ve teşhislerde olan değişiklikler hastalar dermatolojik problemleri açısından değerlendirilmiştir.

Bulgular: 352 pediatrik cerrahi hastaları dermatolojik șikayetler nedeniyle muayene edildi. Bu hastaların 72'si toplamda 80 defa diğer branşlara konsulte edildi. Dört hasta 2'şer kere, 1 hasta 3 kez konsulte edildi. Bu hastaların 68'inin tanısı konsültasyonlar sonrasında değişti.

Sonuç: Dermatolojik hastalıklar açısından pediatrik muayenelerin entegrasyonu nadiren değerlendirilmiş bir durumdur. Bizim düşüncemize göre, bu değerlendirmeler pediatrik dermatoloji ünitelerinin ve bu üniteleri oluşturacak hekimlerin belirlenmesine yardımcı olabilir. Ortak tedavilerin yapılabilmesi açısından yardımcı olabilecek kliniklerinin entegrasyonun önemli olduğunu düşünmekteyiz.

Anahtar Sözcükler: Çocuk, Dermatoloji, Pediatrik dermatoloji, Pediatrik cerrahi, Takım çalışması

\section{INTRODUCTION}

Dermatology and plastic surgery are responsible as the main departments in terms of visits for paediatric dermatology patients. In addition, other departments, such as pediatric surgery, examine some pediatric dermatology patients. Although the departments have common interests, cooperation with these departments for pediatric dermatology has not been studied before. As an expanding branch, treatments for pediatric dermatology diseases may degrade because of the disorganization among disciplines. This process will reduce the number of-attendance as a result of patient and family dissatisfaction. 
Literature about different skin diseases can be easily found. In contrast to this, there are a little published data for the medical teams integrations for pediatric dermatology. Main reason for this is the weakness of the algorithm among the departments in hospitals. Clinic of pediatric dermatology can be structuredas an indispensable unit in hospitals. In our opinion, the importance of the relevant branches for pediatric dermatology units must be determined, firstly. These determinations will help to find out teamwork curriculum and board members of these units. To do this, the authors need to publish their own experiences to demonstrate the effectiveness of their branches on pediatric dermatology.

Dermatologic diseases in pediatric surgery training is available, however, are insufficient during education and training.For all these reasons, paediatric surgery in a retrospective study was designed to determine the interaction with other departments. Paediatric surgery has an important potential to be a part of the team.

\section{MATERIAL and METHODS}

Pediatric surgery documents of Kecioren Education Hospital between 2005 and 2011 were examined. Diagnoses, consultations, and diagnostic changes were evaluated. Diagnose were made by using ICD-10 coding system. Literature-based discussion is made and our proposal is formulated within this discussion.

\section{RESULTS}

Three hundred and fifty two patients were examined for dermal diseases in our clinic (Table I).Seventy-five patients were consulted to various departments, a total of eighty times. These clinics were dermatology, plastic surgery, general surgery, orthopaedics and paediatrics. Seventy-one patients were examined at a clinic; four patients were examined in two clinics and one inthree clinics (Table II). The diagnosis was changed after examination of 68 patients in different clinics (Table III).

Table I: Distribution of the patient visits according to visits and consultations. 2nd and 3rd consultations are showing multiple examinations of some patients.

\begin{tabular}{|c|c|c|c|c|}
\hline Diagnose & No. Patients & $1^{\text {st }}$ Cons. & $2^{\text {nd }}$ Cons. & $3^{\text {rd }}$ Cons \\
\hline Dermal abscess, furuncles and carbuncles & 71 & 6 & 0 & 0 \\
\hline Nail deformities & 129 & 44 & 3 & 1 \\
\hline Dermal benign neoplasms & 67 & 7 & 1 & 0 \\
\hline Congenital malformations of dermal conjoint & 8 & 1 & 0 & 0 \\
\hline Disorders of dermis and subcutaneous tissue & 31 & 11 & 0 & 0 \\
\hline Allergic contact dermatitis, dependent to foods & 2 & 1 & 0 & 0 \\
\hline Viral warts & 3 & 0 & 0 & 0 \\
\hline Dermal Foreign bodies & 7 & 0 & 0 & 0 \\
\hline Local infections of dermis and subcutaneous tissue & 34 & 5 & 0 & 0 \\
\hline Total & 352 & 75 & 4 & 1 \\
\hline
\end{tabular}

Table II: Distribution of the consultations.

\begin{tabular}{|l|c|c|c|c|c|c|}
\hline Diagnose & Cons. & Derma. & Plas. Srg & Orthop & Gen.Srg & Paediatr \\
\hline Dermal abscess, furuncles and carbuncles & 6 & 3 & 0 & 1 & 1 & 1 \\
\hline Nail deformities & 44 & 21 & 11 & 10 & 2 & 0 \\
\hline Dermal benign neoplasms & 7 & 3 & 5 & 1 & 0 & 0 \\
\hline Congenital malformations of dermal conjoint & 1 & 1 & 0 & 0 & 0 & 0 \\
\hline Disorders of dermis and subcutaneous tissue & 11 & 5 & 6 & 0 & 0 & 0 \\
\hline Allergic contact dermatitis, dependent to foods & 1 & 1 & 0 & 0 & 0 & 0 \\
\hline Viral warts & 0 & 0 & 0 & 0 & 0 & 0 \\
\hline Dermal Foreign bodies & 0 & 0 & 0 & 0 & 0 & 0 \\
\hline Local infections of dermis and subcutaneous & 5 & 3 & 0 & 0 & 1 & 1 \\
\hline tissue & & & & & & \\
\hline Total & 75 & 36 & 21 & 12 & 4 & 2 \\
\hline
\end{tabular}


Table III: Diagnose changes and numbers of the changes after consultations are documented.

\begin{tabular}{|c|c|c|c|c|}
\hline Diagnose & Cons. & Diag. Change & No. Patients & Total \\
\hline \multirow{5}{*}{ Dermal abscess, furuncles and carbuncles } & \multirow{5}{*}{6} & Cellulitis & 2 & \multirow{5}{*}{6} \\
\hline & & Hyperpigmentation & 1 & \\
\hline & & Contact dermatitis & 1 & \\
\hline & & Herpes Simplex & 1 & \\
\hline & & Pilonidal sinus & 1 & \\
\hline \multirow{3}{*}{ Nail deformities } & \multirow{3}{*}{44} & Pyoderma & 18 & \multirow{3}{*}{44} \\
\hline & & Tineaunguium & 20 & \\
\hline & & Xerosis cutis & 6 & \\
\hline \multirow{3}{*}{ Dermal benign neoplasms } & \multirow{3}{*}{7} & Atopic dermatitis & 1 & \multirow{3}{*}{5} \\
\hline & & Synovial cysts & 1 & \\
\hline & & Melanocytic nevus & 3 & \\
\hline Congenital malformations of dermal conjoint & 1 & Xerosis Cutis & 1 & 1 \\
\hline \multirow{4}{*}{ Disorders of dermis and subcutaneous tissue } & \multirow{4}{*}{11} & Contact dermatitis & 3 & \multirow{4}{*}{6} \\
\hline & & Atopic dermatitis & 1 & \\
\hline & & Xerosis Cutis & 1 & \\
\hline & & Keloid & 1 & \\
\hline Allergic contact dermatitis, dependent to foods & 1 & Xerosis Cutis & 1 & 1 \\
\hline Viral warts & 0 & 0 & 0 & 0 \\
\hline Dermal Foreign bodies & 0 & 0 & 0 & 0 \\
\hline \multirow{3}{*}{ Local infections of dermis and subcutaneous tissue } & \multirow{3}{*}{5} & Nail Deformity & 1 & \multirow{3}{*}{5} \\
\hline & & Dermatitis & 2 & \\
\hline & & Erythema Intertrigo & 2 & \\
\hline Total & 75 & & 68 & 68 \\
\hline
\end{tabular}

\section{DISCUSSION}

Skin disorders are frequent problems in paediatric age group (1). Six-24\% of paediatric clinics patients suffers from dermatologic problems $(1,2)$. Dermatology, plastic surgery, paediatric surgery and some others also examine skin diseases of children. Therefore, exact percentage of paediatricskin diseases is not reflected by only paediatric clinicsdata. However, in general, clinics relevant to children have published few data for paediatric dermal diseases experiences. All data, collected on children's skin diseases from different departments, starting from paediatric surgery, may provide a functional paediatric dermatology department. In this study, we document our patients diagnose and decision-making during their processes.

Some patients are examined in paediatric and dermatology clinics (3). In most western countries, one-third of paediatric dermatology patients have been treated in paediatric clinics (3). Six-year period, 352 patients were examined for skin diseases in our clinic. As the total number of patients in this period is 9.958, our prevalence for dermatologic disease is $3.5 \%$. Paediatrics clinics have $6-24 \%$ potential for dermal diseases $(1,2)$. All the groups of diseases that were referred to our department might need surgical treatment (4-10). So, the potential for skin disorders in paediatric surgery may be less than paediatrics. We did not find analysis for dermal diseases of some other clinics in the literature. Therefore, our finding can't be compared to them.

Internal medicine, surgery, gynaecology, ear-nose-throat, ophthalmology and rheumatology consulted paediatric patients to dermatology clinics (3). In literature, to our knowledge, there is no published data about paediatric surgery patients consulted to dermatology clinics. Seventy-five of 352 patients were consulted to other departments. These departments were dermatology, plastic surgery, orthopaedics, general surgery and paediatrics. Dermatology consultations were 36 patients (10.5\%). In our whole paediatric surgery population, the dermatology consultation percentage was 0.36 . We also did not find literature data about dermatology consultations for departments. Wenk et al. (3) reported their analysis for dermatology consultation rates among clinics, but this finding is not useful for analysis of other departments. So, our data is a new parameter for the literature. This data show that paediatric surgery does not have high-level impact at paediatric dermatology. Moredata will reveal at least our part in paediatric dermatology. 
Thirty-nine patients were consulted by plastic surgery, general surgery, orthopaedics and paediatrics as shown in Table II. This parameter shows the possible collaborations among these departments. We do not know how this issue cared for by other departments. Also, there is no literature on this subject. The reasons of consultations may be another matter of discussion. In our practice, we did not record the reasons of these consultations. Practically, different departments consultations are made for the skin diseases effecting neighbour tissues or coexisting disease, which are associated with diseases involving their areas of expertise.

Additionally, another finding of our study is the changes in the diagnosis of the consulted most patients. Seventy-five patients were consulted to other departments, as shown in Table III. Diagnose were changed for sixty-eight of these patients. Diagnosis of nail diseases are the most changed diseases among these patients. We understand that the finding is a caution for our practices. Also this finding also shows the importance of consultations and for collaborations. In addition, diagnoses of other diseases often changed after consultations. Therefore, we believe it is accurate indications for consultations.

Second and third consultations as shown in Table I are minor data revealed in our study. Four consultations were made for the second time and one consultation were made for third time. This is due to multiple advisory departments for final decisions had hesitations. Although the sample was small for more than one consultation, we believe that the issue was a reflection of the teamwork and participation. This small group, in our opinion, is one of the proofs for the integration requirements.

In our clinic, 277 dermatology patients were treated without consultation. Our clinic is a second stage paediatric surgery department with acceptance of nearly 2.000 patients per year. Therefore, other paediatric surgery clinics may be expected to be more experienced about patients with skin problems. Data evaluations of these departments may prove our findings.

In conclusion, "Paediatric Dermatology" is promising a future. However, paediatric dermatology in our country, yet, is far from being a complete organization. To our knowledge, the status of worldwide paediatric dermatology practices has not been reported. Therefore, we have not exactly known the progress of paediatric dermatology in other countries. Paediatric surgeons, as some other departments, can treat some skin diseases of children. Therefore, we think that our department is related to paediatric dermatology department. In another perspective, a paediatric dermatology unit will also ease things for paediatric surgery. In our opinion, the slow development of paediatric dermatology is due to the lack of cooperation between the relevant units. We propose to analyse carefully the roles of the various departments for skin diseases. This will be important to build active and worldwide paediatric dermatology units.

\section{REFERENCES}

1. Ogunbiyi AO, Owoaje E, Ndahi A. Prevalence of skin disorders in school children in Ibadan, Nigeria. Paediatr Dermatol 2005;22: 6-10.

2. Inanır I, Sahin T, Gunduz K, Dinc G, Turel A, Ozturkcan S. Prevalence of skin conditions in primary school children in Turkey: Differences based on socioeconomic factors. Paediatr Dermatol 2002;19:307-11.

3. Wenk C, Itin P. Epidemiology of paediatric dermatology and allergology in the region of Aargau, Switzerland. Paediatr Dermatol 2003;20:482-7.

4. Del Giudice PH, Blanc V, Durupt F, Bes M, Martinez JP, CounilIon $E$, et al. Emergence of two populations of methicillin-resistant Staphylococcus aureus with distinct epidemiological, clinical and biological features, isolated from patients with community-acquired skin infections. Br J Dermatol 2006;154:118-24.

5. Koga T, Matsuda T, Matsumoto T, Furue M. Therapeutic approaches to subcutaneous Mycoses. Am J Clin Dermatol 2003;4:537-43.

6. Pariser RJ. Benign neoplasms of the skin. Med Clin North Am 1998;82:1285-307.

7. Walsh JS, Fairley JA. Calcifying disorders of the skin. J Am Acad Dermatol 1995;33:693-706.

8. Rabinowitz LO, Zaim MT. A clinicopathologic approach to granulomatous dermatoses. J Am Acad Dermatol 1996;35:588-600.

9. Mahrle G, Alexander W. Surgical treatment of recalcitrant wart. J Dermatol Surg Oncol 1983;9:445-50.

10. Smith F. Mechanical abrasion to remove pits, foreign bodies, scars, etc. Plast Reconstr Surg 1954;14:236-9. 